'Shalakhmetova G.A., ${ }^{1}$ Aytasheva Z.A., ${ }^{2}$ Alikulov Z.A.

${ }^{1} \mathrm{Al}-$ Farabi Kazakh National University, Kazakhstan, Almaty ${ }^{2}$ L.N.GumilevEuroasian National University, Kazakhstan, Astana

Increasing resistance of wheat to unfavorable environmental factors by pre-sown priming of its grains

'Шалахметова Г.А., ${ }^{1}$ Айташева 3.А., ${ }^{2}$ Аликулов 3.А.

'Ә^-Фараби атындағы Қазақ ұлттық, университеті, Қазақстан, Алматы қ.

${ }^{2} \wedge . Н$. Гумилеватындағы Еуразия ұлттық университеті, Қазақстан, Астана қ.

Бидайдың дәндерін себер алдында праймингтеу арқымы оның қоршаған ортаның қолайсыз факторларына төзімдікігін арттыру
Presowing priming involves soaking seeds under controlled conditions until complete saturation with water or essential components for the further development of plants, seeds followed by drying. AO (aldehyde oxidase) is involved in $\mathrm{ABA}$ biosynthesis, converting abscisic aldehyde to ABA. Seeds of resistent cultivar - NAZ, soaked in a solution of $50 \mathrm{mMmo}-$ lybdate, showed high activity of $\mathrm{AO} 1$, indicating that the maximum saturation molybdenum enzyme. Saratovskaya- 29 was shown that soaked of the seeds in $50 \mathrm{mMmolybdate}$ solution for 24 hours, as these optimal conditions hydrating seed will increase in ABA content of the caryopsis. Excessive ROS formed in the conditions of application of priming, in embryonic tissues during hypoxia induces increasing synthesis of ABA. In seeds during soaked in $50 \mathrm{mMmolybdate}$ solution increased ABA content in 10.5 times of Lutecsens 70 and 5.2 times by soaking the seeds in water. As a result of the priming procedure, which is accompanied by the formation of excess free radicals induced defensive responses in plant cells. Incubation of seeds within 24 hours and 32 hours during this period increased GR activity and almost no imbalance reduced and oxidized glutathione, wheat varieties. Views will data showed that pre-sowing seed priming both varieties NAZ and Saratovskaya 29 led to an increase in the content of endogenous $\mathrm{ABA}$ in 2 times and 1.5 times the antioxidants and as a result has led to an increase in resistance to stress (adverse environmental factors) both varieties.

This paper presents the results of the impact of pre-sowing grain priming maintenance plant hormone $\mathrm{ABA}$, the activity of $\mathrm{AO}$ and antioxidant enzymes in two different varieties of wheat.

Key words: priming, wheat, ABA, AO, abiotic stress, antioxidants

Өсімдіктердің қоршаған ортаның қолайсыз факторларына төзіміділігін күшейту жолдарының бірі - дәндерді себер алдында праймингтеу болып табылаАы. Прайминг Аегеніміз - АәндерАі бақылау жағдайында сумен (немесе басқа маңызды ерітінділермен) әбден қанғанға дейін ылғалдандыру және оларды ары қарай кептіру. Аәндерді праймингтеу олардың ерте бүршіктенуіне, өну пайызының жоғарылауына, өркендердің біркелкі және тез өсуіне, вегетативтік және дәндердің пісу кезеңдерінде өсімдіктерАің өсуінің жақсаруына, дәндердің массасының ұлғаюына алып келеді, сонымен қатар, солардың нәтижесінде өнім, абиотикалық, және биотикалық, стрестерге төзімділік жоғарылайды .

Ы^ғандандыруға пайдаланылған молибдаттың $\left(\mathrm{Na}_{2} \mathrm{MoO}_{4}\right)$ ерітіндісінің билайдың төзімді және төзімсіз сорттарының Аәндерінің өнуін тежемейтін оңтайлы концентрациялары анықта^Аы. Молибдаттың 50 мМ ерітіндісінде суландырырылған төзімді - НАЗ сортының Аәндері альдегидоксидазаның АO1 изоферментінің жоғары белсенділігін көрсетті, яғни ферменттің барынша молибденмен қаныққаны анықталды.Сонымен қатар, бақылаудағы дәндермен салыстырғанда төзімді НАЗ сортының Аәндерін молибдаттың ерітінАісінде праймингтеу абсциз қышқылының (АБҚ) синтезінің 10.5 есе, ал суда праймингтеу - 5.2 есе жоғарылайтынын, антиоксиданттық ферменттердің белсенділігі және суда еритін антиксиданттардың мөлшерінің де артатынын көрсетті. Бүгінгі күні прайминг үрдісіне қатысатын молекулярлық және биохимиялық механизмдер нашар зерттелген. Біз қоршаған ортаның қолайсыз жағдайларында маңызы зор антиоксиданттық фермент - глутатионредуктазаның және АБҚ фитогормонының синтезін іске асыратын альдегидоксидазаның реттеулуін көрсеттік.

Берілген жұмыста себер алдында бидайдың екі сорттарының Аәндерін праймингтеудің АБҚ фитогормонының мөлшеріне, альАегидоксидазаның және антиоксиданттық ферменттердің белсенділігіне әсерінің нәтижелері көрсетілген.

Түйін сөздер: 


\section{INCREASING \\ RESISTANCE OF WHEAT TO UNFAVORABLE ENVIRONMENTAL FACTORS BY PRE-SOWN PRIMING OF ITS GRAINS}


'Шалахметова Г.А., ${ }^{1}$ Айташева 3.А., ${ }^{2}$ Аликулов 3.А.

${ }^{1}$ Казахский национальный университет им. аль-Фараби,

Казахстан, г. Алматы 2Евразийский национальный университет им. Н. Гумилева,

Казахстан, г. Астана

Повышение устойчивости пшеницы к неблагоприятным факторам окружающей среды методом предпосевного прайминга семян
ОАним из многообещающих подходов в повышении устойчивости растений к неблагоприятным факторам окружающей среды яв^яется предпосевной прайминг семян. Прайминг - это замачивание семян в контролируемых условиях до полного насыщения воАой (или Аругими растворами с существенными компонентами), с последующим высушиванием семян. Установлено, что прайминг семян приводит к улучшению роста растений в вегетативный период и в период созревания семян, увеличивается их масса и тем самым повышается урожайность, а также устойчивость к абиотическим и биотическим стрессам .

Определены оптимальные концентрации гидратирования семян устойчивой и неустойчивой сортов пшеницы в растворе момибдатаNa2MoO4, которые не ингибируют прорастание зерна. Зерно устойчивого сорта - НАЗ, гиАратированные в 50 мМ растворе молибдата,обладали высокой активностью изофермента АO1 альдегидоксидазы, показывающие максимальное насыщение фермента молибденом. Кроме того, прайминг семян устойчивого сорта НАЗ в растворе молибдата к повышению синтеза абсцизивой кислоты (АБК) в 10,5 раз и в 5,2 раза при гидратировании зерна в Н2О по сравнению с контролем, а также повышается активность антиоксидантных ферментов и содержание водорастворимых антиоксидантов. На сегодняшний день недостаточно изучены молекулярные и биохимические механизмы, вовлекаемые в процессе прайминга. Нами была показанарегуляция антиоксидантного фермента- глутатионредуктазы и альдегид оксидазы - фермента, осуществляющей биосинтез фитогормона АБК, что имеет огромное значение при неблагоприятных условиях окружающей среды.

В данной работе представлены результаты воздействия предпосевного прайминга зерна на содержание фитогормона АБК, активность альдегид оксидазы (АО) и антиоксидантных ферментов в двух различных сортах пшеницы.

КАючевые слова: 
the ammonium transporter AMT1.1, alters basal defenses generating resistance against Pseudomonas syringae and Plectosphaerellacucumerina. In this work their authors study the role of this ammonium transporter on the basal defenses and the resistance against $P$. syringae and $P$. cucumerina demonstrating that it is a negative regulator of Arabidopsis defense responses [6].

Cross-talk between different signaling pathways has been reported to generate both synergistic and antagonistic defense responses. In some cases this cross-talk might contribute to fine-tune defense responses against some pathogens according to its mode of infection. Using some resistance elicitors such as acibenzolar-S-methyl (ASM), $\beta$-aminobutyricacid (BABA), cis-jasmone (CJ), and a combination of the three compounds, which involve SA and/or JA-dependent signaling pathways, study if these treatments are capable to control infection of spring barley by Rhynchosporium commune under field conditions [7].

Borges and co-workers propose priming crops as a way for controlling biotic and abiotic stresses and focus on the effect of the water-soluble vitamin K3 derivative, known as menadione sodium bisulphite (MSB), as a novel priming agent and as a tool for studying priming mechanisms. The work review the priming phenomenon and the importance of reactive oxygen species (ROS) as key signaling molecules that contribute to control of plant development as well as to the sensing of the external environment and priming induction [8].This method and their potential applications provide a new sustainable approach to crop protection. This technology currently can offer promising molecules capable to provide new long lasting treatments for crop protection against biotic or abiotic stresses.

One of the most promising approaches to improving plant resistance to unfavorable environmental factors is pre-primed seeds. During priming in order to increase stress tolerance in the plant that is of prime agricultural interest.

Presowing priming involves soaking seeds under controlled conditions until complete saturation with water or essential components for the further development of plants, seeds, followed by drying. It was found that the priming of seeds leads to early pipping seeds, increase the percentage of germination, synchronized, rapid growth of seedlings, improving the growth of plants in the growing season and during seed maturation, increased seed weight, and thus increases the yield and resistance to abiotic and biotic stress [9].It has been shown that the priming increases the synthesis of proteins, RNA, DNA in seeds, also increases the activity of antioxidant enzymes catalase, superoxide dismutase, peroxidase, ascorbate peroxidase, glutathione reductase[10, 11]..

The research on Induced Resistance for Plant Defense focuses on the understanding the mechanisms underlying plant resistance or tolerance since these will help us to develop fruitful new agricultural strategies for a sustainable crop protection. To date, insufficiently studied the molecular and biochemical mechanisms involved in the process of priming. We have been shown the regulation of antioxidant enzymes and aldehyde oxidase - an enzyme, carrying out the biosynthesis of plant hormone $\mathrm{ABA}$, in terms of priming is of great importance in the prevention of pre-harvest sprouting seeds. $\mathrm{ABA}$ is a plant growth regulator involved in various processes, including response to environmental stress and seed maturation and dormancy [12]. Dormancy is a mechanism to prevent germination during unfavorable ecological conditions, when the probability of seedling survival is low [13]. A dormant seed is one that is unable to germinate for a specific period of time under a combination of environmental factors that are normally suitable for the germination of the non-dormant seed [14] . In cereal crops, an optimum balance between dormancy and non-dormancy is desirable. Dormancy at harvest is desired because it prevents the germination of the physiologically mature grain (i.e. PHS)in the head prior to harvest, a phenomenon that considerably lowers grain quality and is especially common in cool, moist environments. ABA regulates a number of key events during seed development, such as the deposition of storage reserves, prevention of precocious germination, acquisition of desiccation tolerance, and induction of primary dormancy [15].

In higher plants, $\mathrm{ABA}$ is derived from an epoxycarotenoid precursor that is oxidatively cleaved to produce xanthoxin [ 16 ]. It is known that AO is involved in ABA biosynthesis, converting abscisic aldehyde to $\mathrm{ABA}$, and the by-product of this reaction is superoxide.Following the cleavage, xanthoxin is converted to $\mathrm{ABA}$ by a series of ring modifications to yield abscisic aldehyde, which is oxidized to ABA by $\mathrm{AO}$ (EC 1.2.3.14), a molybdenum-containing enzyme [17 ].

This paper presents the results of the impact of pre-sowing grain priming maintenance plant hormone ABA, the activity of aldehyde oxidase (AO) and antioxidant enzymes in two different varieties of wheat. 


\section{Materials and methods}

In our studies using wheat seeds are sterilized for $5 \mathrm{~min}$ in $1 \% \mathrm{NaClO}$, then washed thoroughly with distilled water.

Priming of wheat seeds was carried out according to the method of Rose [18] in our modification. Seeds of wheat, cultivar - NAZ and Saratovskaya 29 were soaked in a solution of $50 \mathrm{mM} \mathrm{Na} 2 \mathrm{MoO} 4$, $100 \mathrm{mM}$ and $200 \mathrm{mM}$ within a day (24 hours) and then the seeds were dried at $25^{\circ} \mathrm{Ct}=$ for $25-30 \mathrm{~h}$.

Native electrophoresis of aldehyde oxidase performed in alkaline tris-glycine buffer system using $1 \mathrm{~mm}$ plates, $7.5 \% \mathrm{PAGE}$ at $4{ }^{\circ} \mathrm{C}$ for 4.5 hour at a constant current of $35 \mathrm{~mA}$ per gel. As a substrate used benzaldehyde and indole 3-aldehyde. [19 ].Electrophoresis division for glutathione reductase (GR) were carried out as for the AO; gel staining was performed on Pinhero et.al [20]. The intensity of the color bands of enzymes was determined by electronic program Scion Image.

Endogenous ABA content was carried out using a mono-clonal antibody from Sigma (USA) according to the attached methodological instructions.

The experiments were performed in 3-4-fold repetition.

\section{Results and discussion}

In our studies, we hypothesized that the priming of seeds with a relatively high concentration of molybdenum can lead to optimal saturation of seeds of wheat this element and to prevent molybdenum deficiency of the plant.

Accordingly, experiments to optimize the conditions of priming were performed optimum time of seed hydration were selected in $\mathrm{Na} 2 \mathrm{MoO} 4$ salt solution,allowing them to absorb molybdenum to saturation and the optimal concentration of molybdate solution.

Optimal concentrations of soluble molybdenum salt $\mathrm{Na} 2 \mathrm{MoO} 4$, which did not inhibit germination of the wheat seeds were selected. Seeds of wheat two varieties: resistent cultivar- NAZ and unstable Saratovskaya -29 , soaked in a solution $\mathrm{Na} 2 \mathrm{MoO} 4$ $50 \mathrm{mM}, 100 \mathrm{mM}$ and $200 \mathrm{~mm}$ during the day -24 hour (Figure 1.).

Figure 1 shows that seeds of variety NAZ, hydrated in a solution of $50 \mathrm{mM} \mathrm{Na} 2 \mathrm{MoO} 4$, showed high activity of the enzyme, indicating that the maximum saturation molybdenum enzyme. From electrophoregrameAO grain unstable cultivar-Saratovskaya- 29 shows that in the spectrum of this sort is not isozyme AO1. Since the hydration of seeds of both varieties in a $50 \mathrm{mM}$ solution $\mathrm{Na} 2 \mathrm{MoO} 4$ showed high $(80-85 \%)$, germination of seeds, so the concentration of the solution was $\mathrm{Na} 2 \mathrm{MoO} 4$ optimal hydration of seeds of both varieties.

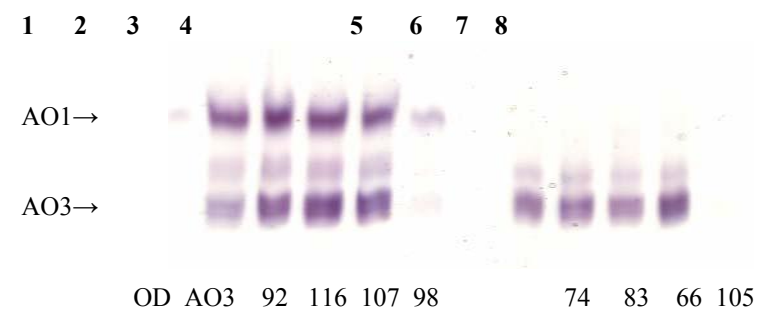

Figure 1 - AO activity in wheat grain NAZ (1 to 4 ) and 29 Saratovskaya ( 5 to 8 ), hydrated in a solution of Na2MoO4: 1 and 5 - Control (H2O); 2 and $6-50 \mathrm{mM} \mathrm{Na} 2 \mathrm{MoO} 4 ; 3$ and 7 $100 \mathrm{mM}$ Na2MoO4; 4 and 8 -200 mM Na2MoO4.

In the next experiment we studied the activity of AO NAZ varieties of seeds in water and hydrated at $50 \mathrm{mM} \mathrm{Na} 2 \mathrm{MoO} 4$ solution for 1 hour, 12 hour, 24 hour, 30 hour and 36 hour. (Figure 2).

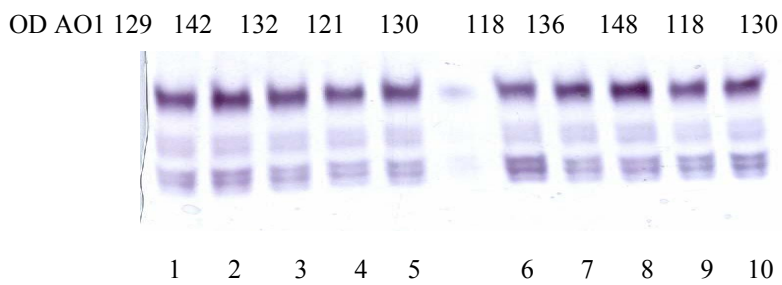

Figure 2 - Activity AO1 NAZ wheat grain, hydrated in $\mathrm{H} 2 \mathrm{O}$ (1 to 5 ) and $50 \mathrm{mM} \mathrm{Na} 2 \mathrm{MoO} 4$ solution (6 to 10 )

Maximum activity was observed in seeds $\mathrm{AO} 1$ of NAZ cultivar, hydrated through water 12 hours after soaking, and the maximum activity of the enzyme from corn, soaked in $50 \mathrm{mMNa} 2 \mathrm{MoO} 4$ solution was observed after 24 hours, i.e. maximum saturation molybdenum. Thus, it was shown that it is advisable to carry out the hydration of the seeds in $50 \mathrm{mM} \mathrm{Na} 2 \mathrm{MoO} 4$ solution for 24 hours, as these optimal conditions hydrating seed will increase in ABA content of the caryopsis. The same conditions for seed hydration have been shown and for the variety Saratovskaya 29 (Figure 3).

Figure 3 shows that the seed varieties Saratovskaya 29, hydrated in water AO3 observed a decrease in activity, but the seeds of this variety shows high activity of AO 24 hours after soaking in a solution of $50 \mathrm{mM} \mathrm{Na} 2 \mathrm{MoO} 4$. 


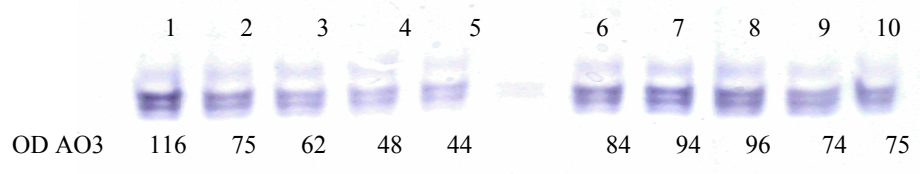

Figure 3 - activity AO3 grain wheat Saratov-29 hydrated in $\mathrm{H} 2 \mathrm{O}$ (C1 to 5) and $50 \mathrm{mM} \mathrm{Na} 2 \mathrm{MoO} 4$ solution (6 to 10$)$

Experiments were conducted in the conditions of application of priming when wheat seeds were placed into the vessels beneath the $1 \mathrm{sm}-2 \mathrm{~cm}$ water or $50 \mathrm{mMmolybdate}$ salt solution for $24 \mathrm{~h}$ at $10^{\circ} \mathrm{C}$. After $t$ such procedure measured the total content of ABA in the embryo and endosperm of wheat were untreated control seeds (Table 1).

Excessive ROS formed in the conditions of application of priming, in embryonic tissues during hypoxia induces the synthesis of ABA and then cause the expression of protective genes, inducing the synthesis of antioxidant enzymes. Table 1 shows that the increase in ABA content of 10.5 times in seeds during hydration in $50 \mathrm{mM}$ $\mathrm{Na} 2 \mathrm{MoO} 4$ solution and 5.2 times by soaking the seeds in water varieties lutescens-70 compared to controls. Saratovskaya-29 showed that increased ABA content in 8 times and 4.5 times, respectively, in $50 \mathrm{mM} \mathrm{Na} 2 \mathrm{MoO} 4$ and $\mathrm{H} 2 \mathrm{O}$ solution and compared with controls.

Table 1 - The content of ABA (pmol / $\mathrm{ml})$ in the embryo and endosperm of two wheat varieties in terms of priming

\begin{tabular}{|c|c|c|c|c|}
\hline \multirow{2}{*}{ variant } & \multicolumn{2}{|c|}{ Lutescens-70 } & \multicolumn{2}{c|}{ Saratovskaya 29 } \\
\cline { 2 - 5 } & $\begin{array}{c}\mathrm{ABA}(\mathrm{pmol} / \mathrm{ml}) \\
\text { embryo }\end{array}$ & $\begin{array}{c}\mathrm{ABA}(\mathrm{pmol} / \mathrm{ml}) \\
\text { endosperm }\end{array}$ & $\begin{array}{c}\mathrm{ABA}(\mathrm{pmol} / \mathrm{ml}) \\
\text { embryo }\end{array}$ & $\begin{array}{c}\mathrm{ABA}(\mathrm{pmol} / \mathrm{ml}) \\
\text { endosperm }\end{array}$ \\
\hline $\mathrm{H}_{2} \mathrm{O}$ & $15,3 \pm 0,39$ & $5,8 \pm 0,87$ & $10,04 \pm 0,31$ & $2,32 \pm 0,12$ \\
\hline $\mathrm{Na}_{2} \mathrm{MoO}_{4}$ & $37,8 \pm 0,48$ & $5,2 \pm 0,63$ & $18,35 \pm 0,39$ & $3,5 \pm 0,08$ \\
\hline control & $2,94 \pm 0,07$ & $1,14 \pm 0,54$ & $1,75 \pm 0,06$ & $0,95 \pm 0,04$ \\
\hline
\end{tabular}

As a result of the priming procedure, which is accompanied by the formation of excess free radicals induced defensive responses in plant cells. In order to control the level of free radicals and protecting cells during exercise stress, the plant tissue containing antioxidant enzymes such as superoxide dismutase, catalase, ascorbate peroxidase, glutathione reductase, etc..

Glutathione reductase (GR) - an enzyme which participates in the conversion of oxidized glutathione in reduced form. The active participation of ascorbate system - glutathione cycle to neutralize ROS and maintaining the redox - balance shown in many examples [20].

We carried out a study of the activity of the GR in two varieties of winter wheat varieties NAE and spring wheat varieties Saratov 29 during priming.

Figure 4 shows the evolution of the activity of the GR NAZ wheat grains during different periods of incubation of seeds in water and a solution of 50 $\mathrm{mM} \mathrm{Na} 2 \mathrm{MoO} 4$.
On electrophoregram of spectrum GR shown that the activity of the GR in the seeds of wheat resistant variety to the the two forms of isoenzymes GR 1 and GR 2 for 12 hours of incubation, the seed activity practically unchanged and the value of enzyme activity are almost identical, indicating that the equilibrium balance reduced and oxidized glutathione. Incubation of seeds within 24 hours and 32 hours during this period increased GR activity and almost no imbalance reduced and oxidized glutathione, wheat varieties NAZ. During 48 hours of incubation the seed, the enzyme activity decreases. Therefore NAZ variety seeds can be incubated for $32 \mathrm{~h}$ in this case will not occur oxidation of DNA, RNA and protein molecules important.

Figure 5 shows that Activityof GR Saratovskaya 29 lower than NAZ winter varieties and seed throughout the incubation period $(48 \mathrm{~h})$, gradually decreases. Also, as for the NAZ varieties, seed varieties Saratovskaya - 29 during the 12 hour incubation, the seeds show high activity and the activity of isoenzymes GR1 and GR2 content 
reduced and oxidized forms of glutathione almost equal. Incubation of the class of seed in water and a solution of molybdate reduces isoenzyme activity GR1 and GR2 activity increases slightly. This suggests that further hydrating the seeds for 32-48 hours results in a significant accumulation of ROS and GR activity decreases and thus accumulate oxidative radicals. Based on the data, seed varieties Saratovskaya 29-hydration is not recommended to subject more than 24 hours in the salt solutions and $\mathrm{H} 2 \mathrm{O}$. Thus, seeds soaked in a solution of molybdenum in priming results in the formation of seeds enriched in molybdenum. This allows AO to increase the level of $\mathrm{ABA}$ in maturing seeds of wheat and thus producing stable seedlings to abiotic stresses.

In our experiments we measured the content of ABA in the mature seeds of the new harvest, which have been subjected to priming (pre-treatment hydration seeds in $\mathrm{H} 2 \mathrm{O}$ and $\mathrm{Na} 2 \mathrm{MoO} 4$ followed by drying), sustainable and non-sustainable Lutescens -70 and Saratovskaya29 cultivars (table 2).

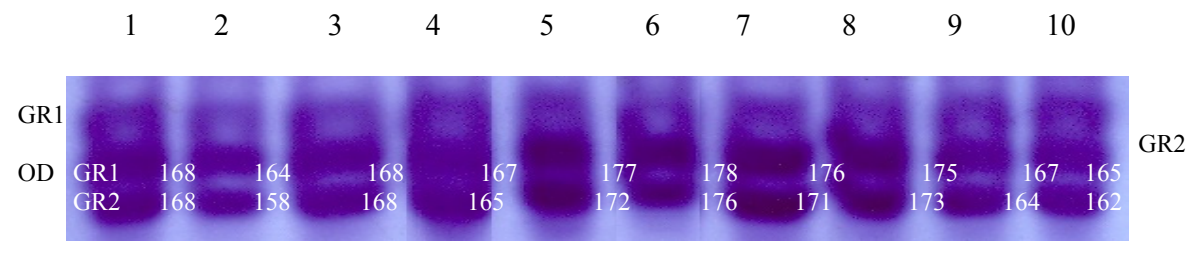

Figure $4-\mathrm{GH}$ activity in grain wheat NAZ incubated in water $(1,3,5,7,9)$ and a solution of 50 $\mathrm{mM} \mathrm{Na} 2 \mathrm{MoO} 4(2,4,6,8,10)$. The seeds were incubated for $2 \mathrm{hr}(1.2) ; 12 \mathrm{hr}(3.4) ; 24 \mathrm{~h}(5,6)$; $32 \mathrm{~h}(7,8)$; 48 hour $(9,10)$

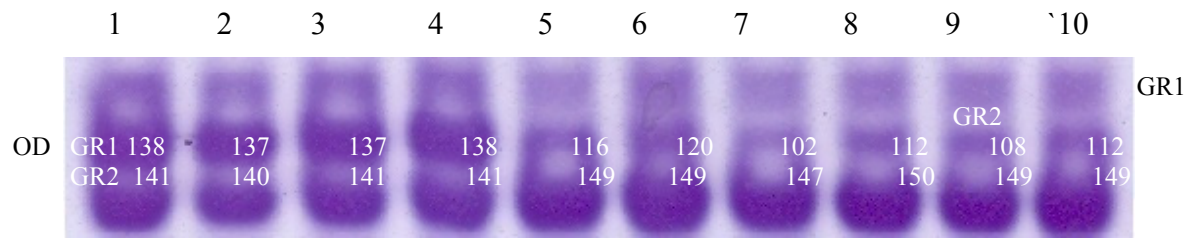

Figure 5 - GR activity in grain wheat Saratovskaya 29, incubated in water $(1,3,5,7,9)$ and 50 $\mathrm{mM}$ Na2MoO4 solution $(2,4,6,8,10)$. The seeds were incubated for $2 \mathrm{hr}(1.2) ; 12 \mathrm{hr}(3.4) ; 24$ h $(5,6) ; 32$ h $(7,8)$; 48 hour $(9,10)$

Table 2 - Content of ABA (pM / ml) in the grain of the new harvest, the resistant variety Lutescens 70 and unstable - Saratovskaya 29

\begin{tabular}{|c|c|c|}
\hline Variants & Lutecsens-70 (grain) & Saratovskaya29 (grain) \\
\hline $\mathrm{H}_{2} \mathrm{O}$ & $4,07 \pm 0,20$ & $2,10 \pm 0,17$ \\
\hline $\mathrm{Na}_{2} \mathrm{MoO}_{4}$ & $5,85 \pm 0,28$ & $3,61 \pm 0,19$ \\
\hline control & $2,93 \pm 0,19$ & $1,84 \pm 0,12$ \\
\hline
\end{tabular}

The presented data show that endogenous ABA content of the resistant variety Lutescens-70 and sensitive varieties Saratov 29, raised grain of the new harvest of wheat in 2 times in comparison with the control variant. It is also shown that a stable grade than for endogenous phytohormone ABA content is 1.5 times higher than the grade unstable Saratov 29. In embodiments with a molybdenum content of $\mathrm{ABA}$ observed maximum grain varieties both compared with the control. These results show that the priming procedure significantly increases the level of stress hormone ABA in seeds in two contrasting varieties of wheat

The correlation between the activity of AO and ABA accumulation in the grain of wheat Lutescens -70 was confirmed conducted native electrophoresis, substrate for AO served aldehyde indole-3 (Figure 6). 


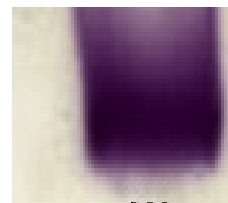

200

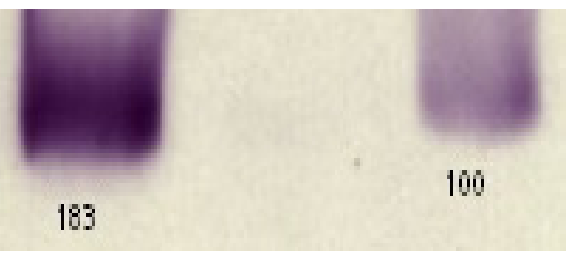

Figure 6 - Active AO in mature seeds of a new crop wheat Lutescens-70 variants: 1 - Na2MoO4; 2 - H2O; 3 - control
In the application of priming seeds of wheat increased resistance, by increasing the content of endogenous ABA and antioxidants. The main watersoluble antioxidants in plant cells are ascorbic acid and glutathione, and antioxidants zhirorast-vorimye - carotenoids, tocopherols and flavonoids. Our results showed that against oxidative stress in cells in priming conditions synthesized enzymatic and nonenzymatic antioxidants (Table 3 )

Table 3 - The total content of water and fat-soluble antioxidants in mature wheat seed varieties Lutescens-70 and Saratovskaya - 29

\begin{tabular}{|c|c|c|c|c|}
\hline Variants & \multicolumn{2}{|c|}{ Lutescens-70 } & \multicolumn{2}{c|}{ Saratovskaya-29 } \\
\hline & embryo & endosperm & embryo & $44.1 \pm 4.5$ \\
\hline $\mathrm{H} 2 \mathrm{O}$ & $139.7 \pm 3.7$ & $49.4 \pm 5.3$ & $95.1 \pm 2.7$ & $51.7 \pm 3.8$ \\
\hline $\mathrm{Na}_{2} \mathrm{MoO}_{4}$ & $153.5 \pm 6.2$ & $48.8 \pm 3.2$ & $107.9 \pm 5.1$ & $53.2 \pm 3.7$ \\
\hline Control & $107.3 \pm 2.5$ & $46.7 \pm 1.7$ & $86.4 \pm 2.8$ & \\
\hline
\end{tabular}

These data show a high antioxidant content in mature seeds of the new crop wheat, in both embodiments, compared with untreated wheat seeds (Control).

Views will data showed that carrying out presowing seed priming both varieties NAZ and Saratovskaya 29 led to an increase in the content of endogenous $\mathrm{ABA}$ in 2 times and 1.5 times the antioxidants and as a result has led to an increase in resistance to stress (adverse environmental factors) both varieties NAZ and Saratovskaya-29.

Thus, the conduct of pre-sowing seed priming increases the resistance of wheat varieties to adverse environmental factors.

\section{References}

1 Andrés A. Borges and Luisa M. Sandalio (2015). Plant Sci. 6:109

2 Luna E., López A., Kooiman J., Ton J. (2014a). Role of NPR1 and KYP in long-lasting induced resistance by $\beta$-aminobutyric acid. Front. Plant Sci. 5:184.

3 Schwarzenbacher R. E., Luna E., Ton J. (2014). The discovery of the BABA receptor: scientific implications and application potential. Front. Plant Sci. 5:304.

4 Luna E., van Hulten M., Zhang Y., Berkowitz O., López A., Pétriacq P., et al. . (2014b). Plant perception of $\beta$-aminobutyric acid is mediated . Nat. Chem. Biol., 10: 450-456

5 Rasool B., Karpinska B., Konert G., Durian G., Denessiouk K., Kangasjärvi S., et al. . (2014). Effects of light and the regulatory Beta subunit composition of protein phosphatase 2A on the susceptibility of Arabidopsis thaliana to aphid (Myzuspersicae) infestation. Front. Plant Sci. 5:405.

6 Pastor V., Gamir J., Camañes G., Cerezo M., Sánchez-Bel P., Flors V. (2014a). Disruption of the ammonium transporter AMT1.1 alters basal defences generating resistance against Pseudomonas syringae and Plectosphaerellacucumerina. Front. Plant Sci. 5:231

7 Walters D. R., Havis N., Paterson L., Taylor J., Walsh D., Sablou C. (2014). Control of foliar pathogens of spring barley using a combination of resistance elicitors. Front. Plant Sci. 5:241.

8 Borges A. A., Jiménez-Arias D., Expósito-Rodríguez M., Sandalio L. M., Pérez J. A. (2014). Priming crops against biotic and abiotic stresses: MSB as a tool for studying mechanisms. Front. Plant Sci. 5:642.

9 Basu R.N. (1994). An appraisal of research on wet and dry physiological seed treatment and their applicability with special references to tropical and subtropical countries. Seed Sci\& Technol. 22(1): 107-127.

10 Agarwal, S., Sairam, R.K., Srivastava, G.C., Tyagi, A., Meena, R.C., 2005. Role of ABA, salicylic acid, calcium and hydrogen peroxide on antioxidant enzymes induction in wheat seedlings. Plant Sci. 169, 559-570.

11 Shalakhmetova G.A. Effect of priming on the antioxidant system of two different wheat genotypes. Biotehnologiya. Teoriya and practice №3,2005, S.58-64 [ Vliyaniyeprayminganaantioksidantnuyusistemudvuchrazlichnyuchsortovpshenistyu] (In Russian) .

12 Zeevaart, J.A.D., Creelman, R.A. (1988) Metabolism and physiology of abscisic acid. Annual Review of Plant Physiology and PlantMolecular Biology39 : 439-473 
13 Black, M., Bewley, J.D., Halmer, P. (2006). The Encyclopedia of seeds: Science, Technology and Uses. Wallingford, Oxfordshire: $\mathrm{CAB}$ International, pp. 40.

14 Baskin, J.M., Baskin, C.C. (2004) A classification system for seed dormancy.Seed Science Research 14(1): 1-16.

15 Fang, J. and Chu, C. (2008) Abscisic acid and the pre-harvest sprouting in cereals.Plant Signaling \& Behavior 3(12): 10461048.

16 Parry, A.D., Neill, S.J., Horgan, R. (1988) Xantoxin levels and metabolism in the wild-type and wilty mutants of tomato. Planta173: 397-404.

17 Leydecker, M.T., Moureaux, T., Kraepiel, Y., Schnorr, K., Caboche, M. (1995) Molybdenum cofactor mutants, specifically impaired in xanthine dehydrogenase activity and abscisic acid biosynthesis, simultaneously overexpress nitrate reductase. Plant Physiology 107: 1427-1431.

18 Rowse HR. (1996). Drum Priming - A non-osmotic method of priming seeds. Seed Sci. \& Technol. 24 : 281-294.

19 Omarov, R.T., Akaba, S., Koshiba, T., Lips, S.H.(1999) Aldehyde oxidase in roots, leaves and seeds of barley (Hordeumvulgare L.). Journal of Experimental Botany50: 63-69.

20 Pinhero R.G., Rao M.V.,Paliyath G., Murr D.P., Fletcher R.A. Changes in activities of antioxidant enzymes and their relationship to genetic and paclobutrazol-induced chilling tolerance of maize seedlings. Plant phisiol. 1997,114;695-704. 